\title{
Indonesia and Discourse of the New International Economic Order (Nieo)
}

\author{
Muhammad Haykal Tarmizi ${ }^{1}$
}

\author{
${ }^{1}$ Universitas Indonesia \\ *Corresponding author. Email: muhammad.haykal81@ui.ac.id
}

\begin{abstract}
This study found that Indonesia had conducted NIEO discourse in the Soekarno Government Era through the NonAligned Movement (NAM) policy and the establishment of the New Emerging Forces (NEFO) in opposition to international world confrontation controlled by the Old Established Forces (OLDEFO). After the Soekarno regime, however, there was no return to NIEO rhetoric until the Widodo administration. From a realist perspective, the conclusion is that the reappearance of NIEO speech in the Widodo era means that Indonesia is repositioning its role in the international world the world of anxiety (Asia \& Africa). From the liberal point of view, the NIEO language in President Jokowi's era as an effort to liberalize of trading partner country markets. (Joko Widodo is sometimes shortened to Jokowi). From a structuralist perspective, NIEO discourse is presented as a set of rhetorical questions intended to create a minimalist nationalist impression.
\end{abstract}

Keywords: New International Economic Order, International Institutions, World Economic System, Economic Nationalism, Indonesia

\section{INTRODUCTION}

Discussion on the issue of changing world systems is currently one of the main issues in the study of international relations. The literature mentions the shift of Western domination toward Asia in the international arena. In the book The Great Convergence and The New Asian Hemisphere, Mahbubani reviews the thinking of a new era in world history that was marked by the end of the domination of Western hegemony (Pieter P. Gero, 2011). In The Great Convergence, Mahbubani includes a manifesto on the future of world politics. The former UN ambassador to Singapore proposed a "one world theory," urging leaders to recognize unified global interests and values and to embrace a more multilateral world order. He argued that the dominance of the US and Europe in international affairs must diminish when new powers emerge, and he outlines the main trends, risks, and opportunities (Ossoff. Jonathan, 2013). Another opinion regarding the discussion of the world economic system is still considered relevant as well. On July 20, 2016, the official website International Institute for Sustainable Development. Quoted from Delia Paul (2016):

The UN issued an updated overview of the major international economic and policy challenges that must be addressed to achieve the aims of the 1974 Declaration on the Establishment of a New International
Economic Order (NIEO). The report finds that some of the ideas raised at the time are still relevant and useful for implementing the 2030 Agenda for Sustainable Development.

The UN issued an updated summary of the economic challenges and key international policies that must be overcome in order to achieve the objectives of the 1974 Declaration on the Establishment of a New International Economic Order. The report found that some of the ideas put forward at that time were still relevant and useful for implementing the 2030 Agenda for Sustainable Development. The UN General Assembly (UNGA) adopted the Declaration on the Establishment of a New International Economic Order and the accompanying action program on 1 May 1974. By doing so, the United Nations promised to take action against injustice in the international system. The goals were eliminating the gap between progress and development, ensuring accelerated economic and social development, and securing peace and justice (Delia Paul, 2016).

The NIEO agenda in Indonesia was explored by Frans Likadja in 1989 under the title "The Relevance of the Concept of the New International Economic Order to Southwest Pacific Countries and Indonesia." In this article Likadja put forward the future steps that would be needed in the form of periodic meetings to discuss challenges and obstacles that were likely to be faced by Indonesia and the other Southwest Pacific nations. He considered it impossible for Indonesia to face domestic 
problems without the cooperation of partner countries. So far, there has been no further study on the continuation of NIEO either in terms of new studies or the renewal of studies. However, the NIEO topic is relevant again in the era of President Widodo's administration (2014-2019). In his speech at the Asia-Africa Summit in Jakarta in April 2015, for example, he argued that the current global economic system - dominated by the World Bank, IMF, and $\mathrm{ADB}$ - is obsolete and it is therefore essential to build a NIEO (Patunru, Mari E. Pangestu, and M. Chatib Basri, 2018). As quoted on the official website of the cabinet secretary:

The view that the world's economic problems can be solved only by the World Bank, the International Monetary Fund (IMF) and the Asian Development Bank $(A D B)$ is an obsolete one."

We must push for reform of the global financial architecture, to eliminate the domination of one group of countries over others," he said at the opening of the second Asian-African Summit.

We are urging the global financial architecture reform to eliminate the domination of the state over other states," "Indonesia is ready to cooperate with all parties to achieve the noble ideals, "Jokowi said.

The President said that the management of the world economy cannot be left only to three international financial institutions, and Asian and African countries are required to build a new world economic order that provides opportunities for new economic forces.

\section{NIEO CONCEPT: ORIGINS AND TRAJECTORIES SOCIAL PENETRATION THEORY}

The new world order began in the era of European decolonialization. The main issue was the development of independent and sovereign decolonialized states. The former colonies had gained de jure independence, but de facto economic colonialism still occurred. This was especially felt in the financial sphere of economic dependence of the countries that had colonized them. The importance of security and equality in the international world and the demand of these countries for international justice is well known through the concept of the NIEO. The idea of NIEO emerged after decolonialization, and illustrated the weaknesses that occurred in economic cooperation between countries. Decolonized countries united in organizations such as the Non-Aligned Movement that they created. They also formed the United Nations Conference on Trade and Development (UNCTAD) where they argued for fairer trade terms and more liberal conditions for financial development (Robert Looney, 1999). A special proposal for a change in the economic system was put forward at the Non-Aligned Summit Conference held in Algiers in September 1973. Following the conference, the Sixth Special Session of the
U.N. General Assembly held a meeting in April 1974. During this session a manifesto entitled "Declaration and Program of Action of the New International Order" was adopted without a vote in December 1974 The UNGA approved the Charter of Economic Rights and Duties of States. This approval was the result of the efforts of the President of Mexico, Luis Echeverria, and the G77 Developing Nations Group.

Mahiou defines NIEO as a means for countries emerging from colonization by European governments to have the opportunity to participate effectively in the political arena. The idea of a NIEO has been proposed and received great recognition in the international, social, and cultural community. In the international economy as such, the NIEO mainly reflects the political claims of the socalled Least Developed Countries in the post-colonial era. There is a belief that Third World nations demand a new economic order that will give them, among other things, permanent sovereignty or control or management of their natural resources and more control over their economic destinies (see Mahinou in Gordon R., 2009).

Referring to the concept defined by Mahiou, Reflecting NIEO as a demand for changes in the world economic order, the statement from President Widodo criticizes the world economic order that can no longer be controlled by the existing agencies. The above explanation raises the issue of how the NIEO concept is developing in Indonesia. This question provided an important basis determining the direction of Indonesia's foreign policy and the role that Indonesia will play in the international arena.

\section{THE TRAJECTORY OF THE NIEO CONCEPT IN INDONESIA}

The Indonesian government was established after the country gained independence in 1945. Since President Soekarno sparked the idea of NIEO through involvement in the NAM and the declaration of the formation of New Emerging Forces (NEFO), Indonesia actually has implemented the same policies. In this paper, several previous studies were synthesized from various sources.

During the Guided Democracy I (1959-1965), President Soekarno issued a decree on July 5, 1959, that declared the 1950 Constitution to be invalid and reenacted the 1945 Constitution (which was ratified on August 18, 1945), dissolved the Constituent Assembly (the body tasked with making a new constitution), and dissolved the Parliament elected in 1955. Due to the change in the power structure, the president had the role of head of government so that political power became centralized in the hands of President Soekarno. At the time, the international political system was unstable; the international world order was divided into the two camps that had won World War II (WWII), the western and eastern blocs; the western bloc was led by America, and the eastern bloc was led by the Soviet Union. A bipolar international situation -according to Morghantau, in the international bipolar system there are two powerful countries (hegemony) that leads the political arena and constitutes a dangerous system- existed that could 
threaten the national interests and the existence of a country. During President Soekarno's administration Indonesia's foreign policy was built on traditional nationalism and anti-colonialism and anti-imperialism and was focused on efforts to maintain independence and protect its sovereignty from all forms of external threats. President Sukarno called for vigilance by all newly independent states of the United States and its allies, who were considered neo-colonialist and imperialist (nekolim). Diplomatic relations with the Netherlands were severed in President Soekarno's speech on August 17, 1960. Furthermore, relations with the Soviet Union and socialist and communist countries were enhanced because they supported President Soekarno's efforts in opposing nekolim. Relationships with newly independent countries in Asia and Africa were also encouraged.

President Sukarno used foreign policy issues to maintain national unity. In the implementation of Indonesia's foreign policy in this period, the president sought to change his international role during the period of limited parliamentary democracy. In addition, he sought to develop an important leadership position among newly independent countries. According to Bunnell (Ganpass Wuryandari, 2008), Indonesia's foreign policy in the Guided Democracy era was influenced more by "the ideological psychological impulse" of President Soekarno himself.

\section{NIEO DISCOURSE ERA OF PRESIDENT SOEKARNO THROUGH NAM AND NEFO}

President Soekarno had revolutionary ambitions, and his anti-imperialist political attitude was Indonesia's foreign policy. His thoughts were strongly influenced by the neo-Marxist-Leninist view (Collected Works, Volume 19, pp.23-28). In the Preamble of the 1945 Constitution, it was clearly written that "Indonesia opposes all forms of colonialism and participates in advancing world peace so that it adheres to the principles of anti-colonialism and anti-imperialism". For this reason, in 1955 the Asian-African Conference (KAA) was held in the presence of 29 countries from the Asian-African continents with the agenda of forming the NAM, identifying and understanding the problem of turmoil caused by the hegemony of the two political poles of the world, and seeking to plan new policies in international relations. The results of the KAA's decision include agreement on the Dasasila Bandung agreement, as a basis for encouraging cooperation between the nations of Asia and Africa.

The NAM was established at the NAM I Summit Conference in Belgrade, Yugoslavia, on September 1-7 in 1961 . The conference was attended by 25 countries. At the summit, it was agreed to establish a movement and it was stressed that the NAM was not going to be a passive movement formed in international politics. On the contrary, it focused on having its own attitude about independence built in the interests of its members. From Indonesia's perspective, NAM had a special role in foreign policy because Indonesia was the initial initiator of NAM through KAA. In addition, President Soekarno was recognized as the originator and founder of NAM.
The Non-Allied Movement aimed to provide support for the freedom to determine the destiny of one's own country, including the sovereignty and national integrity of its member states. In addition, NAM also opposed apartheid as a struggle against imperialism, colonialism, neo-colonialism, racism, disarmament, rejection of the use or threat of force in international relations, social economic development, and international cooperation based on equal rights.

In terms of the international situation, Indonesia was getting closer to the Eastern Block because the Western Block did not support Indonesia's diplomacy in dealing with the Netherlands, especially in the case of West Irian (in Western New Guinea), making Indonesia even more confrontational with the Western Bloc by campaigning against anti-neo-colonialism. One of the triggers of the problem was that the United States did not want to bring the West Irian problem to the UN Security Council Session, making Indonesia take careful political steps. President Soekarno classified the Asian, African, Latin American, and European socialist countries with the NEFO as countries that were confronting the old hegemony of the United States and Western Europe, which he called the Old Established Forces (OLDEFO).

President Soekarno continued to build strength together with non-aligned countries supported by the Soviet Union and the People's Republic of China. In 1963, President Soekarno successfully organized a political party with a political tendency, namely the Games of the New Emerging Force in Jakarta. In 1965, President Soekarno declared Indonesia out of the United Nations because he considered the U.N. to be the shelter for the OLDEFOS countries. The dynamics for an international confrontation in President Sukarno's era were heating up. The idea for a Conference of the New Emerging Forces (CONEFO) aimed at the countries in Asia, Africa and Latin America that had recently gained independence together with European socialist countries was intended to be an agency that would confront the United Nations. However, efforts to establish CONEFO never materialized until after President Soekarno's government fell in 1967.

During President Soekarno's leadership in the 1960s, the Indonesian military was greatly feared because of the proximity of Indonesia to the Soviets. Indonesia received massive amounts of assistance from the world's most advanced military powers. The size of Indonesia's military horrified even America, Great Britain, and Germany and caused them to worry about Indonesia.

In the Soekarno era, political power was said to be too concentrated. In addition to the struggle to maintain independence, various rebellions and feuds among political parties developed that challenged the Old Order era.

\section{THE MEANING OF THE NIEO DURING THE SOEHARTO ERA}

During the Soeharto (Suharto) era, Indonesia was in an unfavourable international position. The domestic economic situation required Indonesia to get foreign 
assistance. The government made a series of foreign aid efforts including: finding food supplies like bulgur, wheat, rice, and instant noodles; providing communication tools to ensure security, and other types of assistance. The attempted coup on September 30, 1965, initiated by the PKI caused a change in the direction of Indonesian politics, especially in foreign policy, which tended to be pro-Eastern in the Soekarno period. It now became a Western bloc nation, especially in terms of the United States.

Soeharto's leadership was very different from Sukarno's, the NIEO rhetoric and the politics of confrontation diminished under Suharto's leadership. Indonesia actually lowered the profile of its foreign policy. President Soeharto prioritized market liberalization and adjusted to the national interests of Indonesia, which was experiencing economic difficulties at the time, by cooperating with the United States. Some examples of policies undertaken were establishing good relations with Western countries and freezing diplomatic relations with China, as well as seeking foreign assistance in order to overcome urgent economic problems.

Changes in the direction of foreign policy were shown through various efforts, including: (1) Stopping the confrontation over Malaysia, which improved relations with and assistance from the U.S. and Japanese. (2) Improving relations with western bloc countries and engaging in other bilateral and multilateral relations. (3) Developing bilateral relations with Japan.

By the mid-1960s, Indonesia's economic condition was in a very bad state. The Indonesian economy suffered because of the political turmoil triggered by President Soekarno, Indonesia's first president. Economic problems were not a major concern for Sukarno. He had spent his life struggling in the political arena. Some examples of policies that had a negative impact on the economy were the severing of relations with Western countriestherefore, isolating Indonesia from the world economy and preventing the country from receiving much-needed foreign aid-and deficit spending through printing money, which caused out-of-control hyperinflation. However, after Suharto took power from Sukarno in the mid-1960s, economic policies underwent a radical change of direction. Indonesia's economic development during Suharto's New Order government can be divided into three periods. Each period is identified by specific policies aimed at specific economic contexts. The first period was economic recovery (1966-1973). The second period was rapid economic growth and stronger government intervention (1974-1982). The third period was growth driven by exports and deregulation (19831996).

Suharto called the economic improvements the Repelita stage for Indonesia. This meant Indonesia would awaken from the economic downturn through planned development.

Soeharto's was an authoritarian regime supported by the military, and it did not respect human rights. Over a period of more than three decades, the government became increasingly out of touch with its citizens. Political and economic decision-making was basically taken from the general public and given to a small group of elite supporters of Suharto based on a system of nepotism and corruption. Decisions were made a small group of elite supporters of Suharto who reaped extraordinary benefits from the sweet fruits of the country's economy. The financial system began to lose control after deregulation measures in the banking sector in the late 1980s. With few restrictions on opening banks and branches, it became increasingly difficult to monitor the flow of money in the Indonesian banking system. A serious lack of financial data, weak regulations and legal frameworks, and the flow of illegal money contributed to the fact that Indonesia suffered the most serious blow when the Asian Financial Crisis. When the monetary crisis that plagued Asia got to Indonesia, it was the beginning of the fall of Soeharto.

\section{THE NEW WORLD ORDER IN THE REFORMATION ERA}

During Habibie's presidency, 30 new laws were approved by the People's Consultative Assembly (MPR), some of which were marked by fundamental differences with politics of the past. A number of important reform actions were instituted. Freedom of the press was started. New political parties and trade unions were established. Political prisoners were released. Presidents' were limited two five-year terms in office. Finally, power was decentralized to the regions.

During the presidency of K. H. Abdurrahman Wahid, pluralism was encouraged, and president Abdurrahman Wahid often made overseas visits. This actually was a waste, but this was done to lift Indonesia's image. As a result of the Soeharto regime, Indonesia was known as a totalitarian country with a low level of democratization. To overcome this, President Abdurrahman visited countries in ASEAN, Africa, Europe, and the Americas. During these visits, active and active free politics were evident. The frequency with which President Abdurrahman visited abroad elicited a positive response from the world. They even opened up opportunities for cooperation (especially trade opportunities).

President Megawati Soekarno Putri began her duty as the fifth president of the Republic of Indonesia by forming the Mutual Cooperation Cabinet. This cabinet had five main agendas, namely, proving the government's firm attitude toward eliminating KKN, arranging steps to save the people from a prolonged crisis, continuing political development, maintaining the rule of law, and creating a socio-cultural situation conducive to advancing the lives of civil society. The goal was to create a prosperous and secure society by increasing security and human rights.

During President Megawati's reign, the MPR revised the 1945 Constitution on November 10, 2001. The amendments included the affirmation of Indonesia as a country of laws with sovereignty in the hands of the people. One of the important changes related to the general election was the change in the procedure for electing the president and vice president, who are now elected directly by the people beginning with the 2004 elections. Thus, the people now participate in general 
elections to elect legislative candidates, president, and regional heads separately.

Reviewing President Widodo's statement at the AsiaAfrica Summit in Jakarta in April 2015, the President said that the management of the world economy could not be left to only three international financial institutions, and Asian and African countries were required to build a new world economic order that provided opportunities for new economic forces.

Historically the existing world economic order was the result of the post-cold war, which was largely developed by the United States, with the justification of reconstructing the international economic system after World War II that had caused huge economic losses to the world. The establishment of international institutions, the IMF, the World Bank, and the General Agreement on Trade \& Tariff laid the foundation for the global economic order in international trade and capital flows

The 1997-1998 eruption of the Asian financial crisis triggered widespread suspicion of the governance of the IMF and the "Washington Consensus" behind it and accelerated increased awareness of the need for regional cooperation throughout Asia. The outbreaks of the 2008 financial crisis in the United States, and the 2010 sovereign debt crisis in Europe changed the old belief that the economies of the developed countries were immunized from financial crises. As the international economic system is increasingly unable to deal with the detection, prevention, and handling of crises caused by waves of globalization. Therefore, regional or crossregional economic governance platforms will play an increasingly important role.

The era is seen as the beginning of a democratic period with open and liberal politics. In this new era, broad autonomy was granted to the regions, which were no longer fully controlled by the central government (decentralization). The basis for this transition was formulated in a law approved by Parliament and signed by the Indonesian President in 1999 calling for the transfer of governmental power from the Central Government to regional governments. This development can be seen in the strengthening of regional institutions between Brazil, Russia, India, China, and South Africa. Indonesia has also strengthened its international role by negotiating mega-regional free trade agreements such as the Regional Comprehensive Economic Partnership, the Trans-Pacific Partnership, and the Trans-Atlantic Trade and Investment Partnership (He Fan \& Ye Qianlin, 2017).

\section{CONCLUSION}

The international world economic order continues to shift. Initially it was divided into the two strongholds of the victorious World War II ideologies represented by America and the Soviet Union. It then shifted to a unipolar stage after the American victory in the Cold War and formed international agencies in all fields now the assumption is that the order of the world economy has shifted to multipolar with the emergence of a third world power involving countries starting with China. One of these countries is Indonesia. Therefore, the state must be able to play the proper role in the political constellation.
The government of President Joko Widodo gave rise to a revival of a stronger nationalistic feeling and sought to play a central role in the international arena through various collaborative policy efforts. This is an attempt to open a discussion about the NIEO or international world order by strengthening cooperation. Policies in controlling the country's economic destiny.

There are two conclusions about the dynamics of the reappearance of the NIEO discourse that was first coined by President Soekarno that need to be tested again in the next study. First, the emergence of the NIEO discourse in President Widodo's term in office is a political step to declare the failure of international economic institutions to carry out their functions. Statements from President Jokowi at international meetings are a rhetorical appeal to strengthen regional cooperation between Indonesia and Africa. Second, Indonesia is a G20 raising power in the constellation of the international system that has shifted to a multipolar configuration. The country wants to reposition its role in the international world as a hegemonic state among the third world countries.

\section{REFERENCES}

[1] He Fan \& Ye Qianlin, 2017 World Economic Order: Present and Future, dalam Parallel Perspectives on the Global Economic Order, CSIS "Center for Strategic \& International Studies.

[2] Bunnel in Wuryandari 2008 Ganpass (ed.). Indonesian Foreign Policy in the Middle of the Domestic Politics Vortex, Jakarta: P2P-LIPIOssoff, Jonathan (2013). Book Review: The great convergence: Asia, the west, and the logic of one world by Kishore Mahbubani accessed from https://blogs.lse.ac.uk/lsereviewofbooks/2013/05/15 /book-review-the-great-convergence-asia-the-westand-the-logic-of-one-world.

[3] Charter of Economic Rights and Duties of States: United Nations General Assembly Document A/RES/29/3281 of 12 December 1974, http://www.un-documents.net/a29r3281.htm.

[4] Delia 2016, Paula. UN Reports on Progress towards New International Economic Order accessed from http://sdg.iisd.org/news/un-reports-on-progresstowards-new-international-economic-order/

[5] Fesseha Mulu Gebremariam, (2009) "New International Economic Order (NIEO): Origin, Elements and Criticisms", Department of Governance and Development Studies, Jimma University, Ethiopia International Journal of Multicultural and Multireligious Understanding. vol. 4, no. 3, 22-28.

[6] Gordon, R, The Dawn of a New International Economic Order Villanova University School of Law, B.A., J.D., New York University; L.L.M., London School of Economics and Political Sciences. 
Pp. 131-155 [Vol. 72:131] (2009). This Article is also available at http://www.law.duke.edu/journals/lcp.

[7] Hermansyah, A, Jokowi questions Indonesia's slow economic growth https://www.thejakartapost.com/news/2018/01/06/j okowi-questions-indonesias-slow-economicgrowth.html, Jakarta, Sat, January 6, 2018 diakses 6 Maret 2019, 12.20 WIB

[8] Kementrian Luar Negeri,'President Jokowi Talked about the Problem of World Economy at AM IMFWB 2018", https://www.kemlu.go.id/en/berita/Pages/PresidentJokowi-Talked-about-the-Problem-of-WorldEconomy-at-AM-IMF-WB-2018 diakses 5 Maret 2019, 14.20 WIB

[9] Looney, R 1999, New International Economic Order, in Routledge encyclopedia of international political economy ISBN 0-415-14532-5.

[10] Matthew P. Goodman, Parallel Perspectives on the Global Economic Order, The Jakarta Post https://www.csis.org/analysis/parallel-perspectivesglobal-economic-order diakses 4 Maret 2019, 14.20 WIB.

[11] Omotayo Olaniyan, R (March-April 1987), - New International Economic Order (NIEO): a review Nigerian Forum, Nos, vol. $3 \& 4$.

[12] Pritchett, L (1997), Divergence, Big Time, Journal of Economic Perspectives, vol. 11, no. 3, 3-17.

[13] Strategic Assessment, Centerofrisk-sia“'Indonesia President Jokowi calls for new, more equal global economic order." 2018, https://www.centerofrisksia.com/indonesian-president-jokowi-calls-for-newmore-equal-global-economic-order/ October, diakses, 13.20 WIB Maret 2019, 66.

[14] Seager, A, \& The The Guardian life insurance company of America 3 June 2010, China and the other Brics will rebuild a new world economic order, Sun, https://www.theguardian.com/business/2010/jan/03 /china-brics-global-economy-america-europeet 2019, 18.20 WIB.

[15] United Nations Conference on Trade and Development (UNCTAD), "the Least Development Countries Report 2017" accessed from https://unctad.org/en/PublicationsLibrary/ldcr2017_ en.pdf.

[16] UN Documents Gathering a body of global agreements, Resolution adopted by the General Assembly 3201 (S-VI). Declaration on the establishment of a New International Economic Order 1 May 1974.

[17] UN, Documents, Gathering a body of global agreement, Resolution adopted by the General Assembly 3281 (XXIX). Charter of economic rights and duties of States - Twenty-ninth session.

[18] V. Nicholas, "The Drivers of Economic Inequality: A Backgrounder for Oxfam's Inequality Campaign," Oxfam America Research Backgrounder series (2014): www.oxfamamerica.org/publications/thedrivers-of-economic-inequality-the- primer. 